UDC 338.439.02

JEL: F63, Q18, Q19

\section{Nato Jabnidze}

Doctor of Business Administration, Assistant Professor, Batumi Shota Rustaveli State University, Batumi, Georgia

E-mail: n.jabnidze@gmail.com orcid.org/0000-0002-5557-6109

\section{Leila Tsetskhladze}

Doctor of Business Administration, Assistant Professor,

Batumi Shota Rustaveli State

University,

Batumi, Georgia

E-mail: Cecxladze.leila@bsu.edu.ge orcid.org/0000-0003-1414-872X

\section{Ia Meskhidze}

Doctor of Business Administration, Associate Professor Batumi Shota Rustaveli State University

Batumi Shota Rustaveli State

University,

Batumi, Georgia

E-mail: Meskhidze.ia@bsu.edu.ge orcid.org/0000-0003-1694-122X

Received: March 3, 2021

Accepted: April 26, 2021

DOI:10.31520/2616-7107/2021.5.2-2

(C) Economics. Ecology. Socium, 2021 CC BY-NC 4.0 license

\section{FOOD SECURITY PROBLEMS FOR DEVELOPING COUNTRIES IN THE CONDITIONS OF COVID-19: CASE OF GEORGIA}

Introduction. Food security has not been a concern of any particular state and is a global problem for already a long time. It, as an economic category in the scientific literature, is considered from the position of ensuring the security of the global world problem, regions, individual countries, population groups and individual people. It is a multifaceted issue, closely linked to other security issues, and has a great impact on the national safety situation, which in turn is an economic, social and political category. COVID-19 has created a large-scale economic crisis. The pandemic has had a major impact on food security and the field of nutrition. The crisis has affected food systems and threatened public access to food, raising the issue of food self-sufficiency in countries.

Aim and tasks. In order to assess food security, the paper examines the self-sufficiency coefficients of basic agro-food products in Georgia under the conditions of the World Pandemic, and evaluates its components: local production, import, export. In addition, local production trends have been analyzed,

Results. Thus a study of the current state of the agrofood sector shows that the problem of providing the population with food is becoming more acute. The pace of development of the agro-food sector lags significantly behind the growth rates of other sectors of the economy. The current economic growth has not yet created the conditions for sustainable economic development: The level of supply of essential agro-food products is quite low, the number of jobs has not increased substantially, the level of income is low, poverty rates are still high and the food deficit is filled mainly with imported products.

Conclusions. This study showed that the issue of the food security is still unresolved for Georgia. Despite the state support activities, the agro-food sector still needs assistance. We have developed recommendations, the consideration of which will significantly contribute to food supply of the markets and food supply to the population.

Keywords: agro-food products, local production, food independence, self-sufficiency coefficients. 
УДК 338.439.02

JEL: F63, Q18, Q19

\section{Нато Джабнідзе}

Доктор економічних наук, доцент, Батумський державний університет Шота Руставелі

Батумі, Грузія

E-mail: n.jabnidze@gmail.com orcid.org/0000-0002-5557-6109

\section{Лейла Цецхладзе}

Доктор економічних наук, доцент, Батумський державний університет Шота Руставелі

Батумі, Грузія

E-mail: Cecxladze.leila@bsu.edu.ge orcid.org/0000-0003-1414-872X

\section{Ія Месхідзе}

Доктор економічних наук, доцент, Батумський державний університет Шота Руставелі

Батумі, Грузія

E-mail: Meskhidze.ia@bsu.edu.ge orcid.org/0000-0003-1694-122X

Отримано: 3 Березня, 2021

Прийнято: 26 Квітня, 2021

DOI:10.31520/2616-7107/2021.5.2-2

(C) Економіка. Екологія. Соціум, 2021 CC BY-NC 4.0 ліцензія

\section{ПРОБЛЕМИ ПРОДОВОЛЬЧОЇ БЕЗПЕКИ ДЛЯ КРАЇН, ЩО РОЗВИВАЮТЬСЯ В УМОВАХ СОVID- 19: ПРИКЛАД ГРУЗЇ̈}

Вступ. Продовольча безпека вже давно не $\epsilon$ проблемою конкретної держави, вона являє собою глобальну проблему. Це багатоаспектний питання, тісно пов'язаний 3 іншими проблемами безпеки, який чинить серйозний вплив на національну безпекою, яка, в свою чергу, $\epsilon$ економічною, соціальною та політичною категорією. COVID-19 викликав масштабну економічну кризу. Пандемія зробила серйозний вплив на продовольчу безпеку і положення в сфері харчування. Криза зачепила продовольчі системи i поставив під загрозу доступ населення до продовольства, а також на порядку денному постало питання про продовольчу самозабезпеченості країн.

Мета і завдання. Метою статті $\epsilon$ вивчення коефіцієнтів самозабезпеченості основними агропродовольчих товарами в Грузії в умовах світової пандемії з метою оцінки продовольчої безпеки, оцінки їі таких компонентів, як: місцеве виробництво, імпорт, експорт. Аналіз тенденції місцевого виробництва, визначення взаємозв'язку між виробництвом агропродовольчих товарів і коефіцієнтами самозабезпеченості.

Результати. Дослідження сучасного стану агропродовольчого сектору показало, що проблема забезпечення населення продуктами харчування стає все більш гострою. Темпи розвитку агропродовольчого сектору значно відстають від показників темпів зростання інших секторів економіки. Поточний економічне зростання ще не створив умов для стійкого економічного розвитку: рівень задоволеності необхідними агропродовольчих товарами досить низький, кількість робочих місць істотно не збільшилася, рівень доходів низький, рівень бідності все ще високий, а нестача продуктів харчування, в основному, заповнюється за рахунок імпортних продуктів.

Висновки. Дане дослідження показало, що проблема продовольчої безпеки для Грузії досі не вирішена. Незважаючи на заходи активної державної підтримки, агропродовольчий сектор як і раніше потребує допомоги. Нами розроблені рекомендації, розгляд яких істотно посприяє продовольчого забезпечення ринків і продовольчого забезпечення населення.

Ключові слова: трудова дисципліна, робоче середовище, трудова мотивація, трудова етика. 
Introduction. Signs of national food security are the provision of food needs mainly at the expense of internal sources, the possibility of economic and physical access to food for all groups of the population, efficient and competitive agricultural production, public and individual health, high food quality and environmental safety, ability to prevent internal, external and environmental threats due to various risks, public confidence in the effective conduct of agricultural policy, achieve sustainable economic growth and expanded reproduction, which will meet the changing needs of the population for food.

In modern conditions, food security is considered to be a key element of national security. According to Georgia's Agriculture and Rural Development Strategy 2021-2027, "it is important to ensure the country's food security and food safety, which is a main obligation of the Government of Georgia. The development of the rural type areas of Georgia is important for solving such tasks as: food security, environmental protection, economic development, creating a high standard of living and state security" (Georgia, 2019). Thus, food security is a state of the economy in which, despite the conjuncture of world markets, the provision of food to the population is guaranteed in quantities that meet scientifically sound parameters and medical norms of consumption.

The problem of food security is very relevant for modern Georgia and reflects the non-compliance with the requirements of the society for food production, which is caused by low agricultural productivity, lack of material and technical base, degradation of the rural social sphere, differentiation of income, reduction of food quality due to environmental pollution. Without ensuring food security, it is impossible to solve the problems facing the state and the economic development of the country.

Problems with food provision in Georgia have recently been considered by scientists and experts as a particularly urgent object of research. The issue is exacerbated by the fact that the growth trends of local agro-food production can not ensure the formation of an optimal structure of food balances, the existing parameters of agro-food production can not achieve a safe level of self-provision (Kharaishvili, Natsvlishvili, 2020).

The research process uses methods of induction and deduction, analysis and synthesis, comparison. The study also uses the following statistical methods: observation, aggregation, grouping, selecting and more. The paper reflects the existing Georgian and foreign scientific papers on food safety issues, publications, researchers conducted by international organizations (King et al., 2017). In-depth interviews were conducted with farmers and agrarian sector experts in accordance with the qualitative research method.

The results and overview of the survey. The Kovid-19 pandemic, which is widespread around the world, has had a major impact on the state of food security and nutrition. The crisis has affected food systems and put the access for food at risk.

The food system covers all areas of activity related to food processing, distribution, preparation and use. The three components of food systems include the food supply chain, the food environment, and consumer behavior. Due to the quarantine regimes forcibly introduced by the countries, failures have occurred not only in the food supply chains, but also the world economy has experienced a downward trend. Revenues have fallen, prices for a range of food products have risen, access to food has fallen, food rights have been challenged, and the concept of sustainable development, Transforming Our World: A 2030 Agenda for Sustainable Development, has been threatened and hampered. The second goal, which aims to eradicate hunger, is to promote food security and sustainable agriculture. (UN, 2016) It should be noted that even today the situation is unstable, constantly changing and characterized by high uncertainty. The global concept analyzes six aspects of food security (Fig. 1). There is a correlation between the global pandemic and these aspects, which shows that all of them need to be considered in terms of food security when analyzing the consequences of the crisis. 


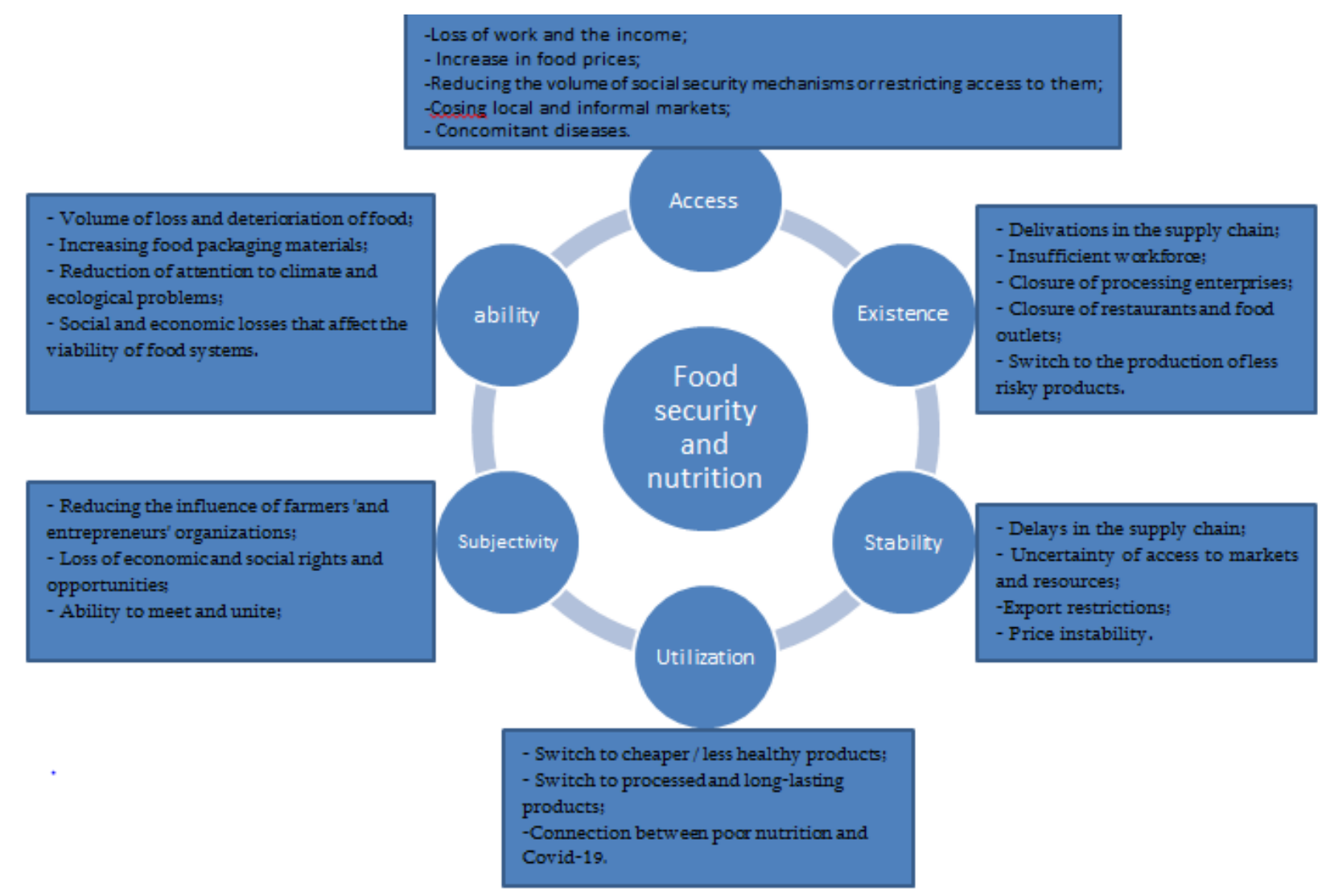

Fig.1. Trends in Covid-19 Interaction on Six Aspects of Food Security.

Source: author's calculations based on Adapted from the source by the authors - Food Security and Nutrition: Building a Global Narrative towards 2030. Report 15. Rome, HLPE.

Food systems, food security and nutrition are affected by new complementary and amplifying trends, such as food supply chain failures, loss of income, rising inequalities, social security program failures, fluctuating local food prices, (Klassen and Murphy, 2020; Clapp and Moseley, 2020; Laborde et al., 2020).

There may also be a reduction in the productivity of the food sector, which will depend on the duration of the pandemic and the measures taken to prevent it. It should be noted that in the first months of the Covid-19 explosion, some food-exporting countries imposed restrictions on the export of major crops such as rice, wheat, and buckwheat. This has led to problems in the global movement of these goods and an increase in their prices compared to other products (Laborde et al., 2020; O'Hara, Toussaint, 2021).

Some countries, predominantly developing countries, become particularly vulnerable to such failures, as their dependence on food imports is high and the population also faces unfavorable food security conditions.
In addition, migrant workers on seasonal farms, who made significant contributions to food production, were faced with the problem of relocation, thus limiting the incomes of workers in poor countries. According to the World Labor Organization, 400 million jobs were lost in the second quarter of 2020, especially in developing countries. The second circumstance is also noteworthy, it is the increase of the population's desire to produce their own products and provide their own food security and food, which has led to an increase in interest in gardening and horticulture. Following the outbreak of the pandemic, food security, ie access to food and basic necessities, has become a major challenge for Georgia. It showed a high degree of dependence on Georgia's imports and a low level of satisfaction with essential agro-food products. Georgia satisfies only $15 \%$ of its wheat consumption with domestic production, the rest is supplied by Russia and Ukraine. Sugar is thoroughly imported. The domestic supply in the meat market is $47 \%$, while the self-sufficiency in poultry is $31 \%$. 
Vegetable oils are also imported and $90 \%$ of imports come from Russia. We have a relatively reliable situation and a high rate of selfsufficiency in the commodity categories of corn
$(70 \%)$, potatoes $(93 \%)$, vegetables $(62 \%)$, eggs $(96 \%)$, in the commodity categories of milk and dairy products $(81 \%)$ (Table 1$)$.

Table1. Food safety indicators for 2018-2019 of Georgia

\begin{tabular}{|c|c|c|c|c|c|c|c|c|c|c|c|c|}
\hline & \multicolumn{3}{|c|}{$\begin{array}{c}\text { Local Production } \\
\text { (thousand }\end{array}$} & \multicolumn{3}{c|}{$\begin{array}{c}\text { Export } \\
\text { (thousand tons) }\end{array}$} & \multicolumn{3}{c|}{$\begin{array}{c}\text { Import } \\
\text { (thousand tons) }\end{array}$} & \multicolumn{3}{c|}{$\begin{array}{c}\text { Self-provision coefficient } \\
\%\end{array}$} \\
\hline & 2018 & 2019 & $\begin{array}{c}\text { change } \\
\%\end{array}$ & 2018 & 2019 & $\begin{array}{c}\text { change } \\
\%\end{array}$ & 2018 & 2019 & $\begin{array}{c}\text { change } \\
\%\end{array}$ & 2018 & 2019 & $\begin{array}{c}\text { change } \\
\%\end{array}$ \\
\hline Wheat & 107 & 101 & -9.3 & 24 & 19 & $-20,8$ & 643 & 587 & $-8,7$ & 15 & 15 & 0 \\
\hline Corn & 194 & 207 & 6.7 & 1 & 1 & 0 & 80 & 90 & 12,5 & 71 & 70 & $-1,6$ \\
\hline Potatoes & 238 & 195 & $-18,06$ & 28 & 4 & $-85,7$ & 24 & 19 & 79 & 102 & 93 & $-8,8$ \\
\hline Vegetables & 142 & 161 & 13.4 & 13 & 12 & $-7,7$ & 108 & 110 & 1,9 & 59 & 62 & 5.0 \\
\hline Grapes & 260 & 294 & 13.08 & 90 & 101 & 12 & 1 & 1 & 0 & 152 & 151 & 0.7 \\
\hline Meat & 72,6 & 69,5 & -4.3 & 16,7 & 10,4 & $-37,7$ & 82,7 & 89,6 & 8,3 & 52 & 47 & -9.6 \\
\hline $\begin{array}{c}\text { Milk and } \\
\text { dairy products }\end{array}$ & 555 & 562 & 1,2 & 4 & 9 & 125 & 133 & 143 & 7,5 & 81 & 81 & 0 \\
\hline Poultry & 22,6 & 22,8 & 0.88 & 8,6 & 4,2 & $-51,1$ & 51,8 & 54,4 & 5.0 & 34 & 31 & 8,8 \\
\hline Eggs, million & 635 & 661 & 4.09 & 4 & 5 & 25 & 11 & 32 & 190 & 99 & 96 & $-3,0$ \\
\hline
\end{tabular}

Source: Calculated based on statistics by the authors (Georgia, 2021)

The food self-sufficiency coefficient shows the level of self-provision of its own resources, as well as the nature of dependence on imports. Accordingly, under conditions of invariability of other variables, local production growth has a positive effect on the selfprovision coefficient. If we consider imports, then conversely, in the case of its growth, the coefficient of self-provision decreases in the absence of other variables. As for exports, the higher it increases, the higher the value of the self-provisionh coefficient, if other variables are unchanged (Talikadze, 2017). In addition to export and import indicators, local production of agro-food products is affected by indicators such as fall and spring sown areas of agricultural crops, yield. Also, the number of cattle and poultry. However, other external factors also affect the production rate. For example, weather variability, natural disasters, etc.

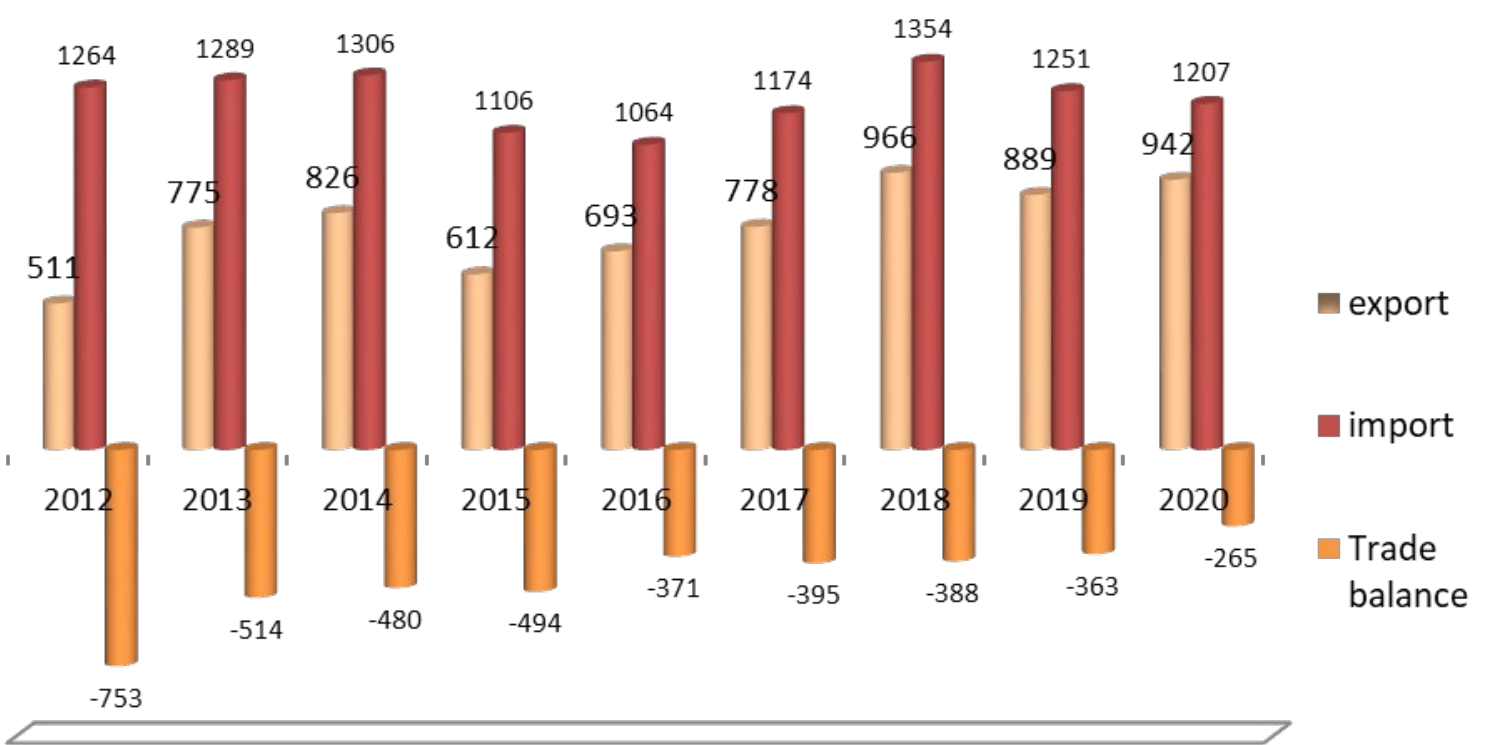

Fig. 2. Foreign trade in the agro-food sector (million USD)

Source: Calculated based on statistics by the authors (Georgia, 2021) 
In general, as Figure 2 shows the volume of exports in 2020 compared to 2012 is increased by $84 \%$, compared to 2017 by $21 \%$, and compared to 2019 by $5 \%$. The reason for this is the increase in the volume of agro-food production, as well as inflationary processes and exchange rate fluctuations. If we compare the data of 2019-2020, we will see that exports of agro-food products increased by $6 \%$, imports of agro-food products decreased by $4 \%$, and the negative trade balance in the agro-food sector decreased by $27 \%$. At the same time, in 2020 , imports exceeded exports by 1.3 times, while in 2012, imports exceeded exports by 2.4 times. (Rural, 2021). Despite this achievement, we consider it unsuccessful that the import of primary agricultural and food products significantly exceeds the volume of exports over the years, due to the low volume of production of these products and the weak competitiveness of the sector compared to foreign producers. (Derii, Koval, Sedikova 2018; Jabnidze, Tsetskhladze, Meskhidze, 2020).
The main criterion of food security is the provision of safe food for the population, while on the other hand, it is an indicator of food selfprovision, which means meeting the food needs of the population of the country at the expense of maximum use of local resources. (Talikadze N., 2017) In parallel with the restrictions related to movement, Georgia's trading partner countries have set quotas and restrictions on various food products. For example, on April 1, 2020, the Russian Ministry of Agriculture imposed a quota on grain exports, and on April 26 , it completely banned the export of wheat, prompting the government to ask for support from strategic partners (US) to replenish wheat stocks. This again made clear the problem of import diversification and especially the reduction of high dependence on Russia.

By early 2020, world grain supplies were at record levels and there was no food shortage. However, uncertainties arising from the virus may change the trend and affect production volume in the future.

Table 2. World grain production (million tons)

\begin{tabular}{|c|c|c|c|c|c|c|}
\hline & & 2018 & 2019 & 2020 & $\begin{array}{c}2019 \text { year compared } \\
\text { to } 2020, \%\end{array}$ & $\begin{array}{c}2020 \text { year compared } \\
\text { to } 2019, \%\end{array}$ \\
\hline \multicolumn{2}{|l|}{ World } & 2647.4 & 2708.8 & 2761.3 & 2.3 & 1.9 \\
\hline \multirow{2}{*}{$\begin{array}{l}\text { Among } \\
\text { them }\end{array}$} & $\begin{array}{l}\text { Developing } \\
\text { countries }\end{array}$ & 1615.3 & 1650.7 & 1686.8 & 2.2 & 2.2 \\
\hline & $\begin{array}{l}\text { Developed } \\
\text { countries }\end{array}$ & 1032.1 & 1058.1 & 1074.5 & 2.5 & 1.6 \\
\hline \multicolumn{2}{|c|}{ Wheat } & 732.1 & 760.0 & 774.0 & 3.8 & 1.7 \\
\hline \multicolumn{2}{|c|}{ Large grains } & 1408.0 & 1445.3 & 1474.1 & 2.6 & 2.0 \\
\hline \multicolumn{2}{|c|}{ Rice } & 507.3 & 502.8 & 513.2 & -0.9 & 2.1 \\
\hline
\end{tabular}

Source: Adapted FAO. CROP PROSPECTS and FOOD SITUATION. Quarterly Global Report.

As Table 2 shows, global grain production by 2020 has increased by $1.9 \%$ compared to the previous year, although it lags behind the similar figure for 2019-2020 (2.3\%). The latest FAO forecast for 2021 is positive and is expected to increase wheat yields to 780 million tons.

Despite the FAO's promising forecasts, prices for certain goods in the Georgian market have risen significantly, including bread and bakery products, meat, vegetable and animal fats, and more. Maintaining the price of bread is the most important at this stage, because due to low incomes, the ration of a large part of the population of Georgia is mainly filled with bread and bread products. Although FAO is not a wheat producing country, Georgia can produce only 3 months of wheat for the country if the sown areas are fully utilized, while scientific research has shown that 12 out of 20 world-famous wheat species are native to front Asia and 8 species originated in the South Caucasus. In total, 14 types of wheat, more than 150 varieties, forms and aboriginal varieties are described in Georgia.

Georgia consumes 700-800 thousand tons of wheat per year, of which only $15 \%$ is local, the rest is imported mainly from Russia. The demand for Russian wheat in the world has increased significantly. The price of one ton of Russian wheat is $250-260$ USD, which is $25 \%$ more than the previous period. 
According to the Russian Ministry of Agriculture, wheat exports in 2020 increased by 20 percent compared to the previous year and reached 300,000 tons. Major buyers of Russian wheat are Turkey, Egypt, Iran, Saudi Arabia, China and Bangladesh, which have significantly increased their wheat purchases. Imports of Russian wheat in Georgia are growing similarly to other countries.
In particular, in January-November 2020 alone, 448,400 tons of wheat were imported from Russia to Georgia, which is $18 \%$ more than in the same period last year. In addition, the share of Russian wheat in total imports has increased. In particular, if in January-November 2019 the share of Russian products in total imported wheat was $87 \%$, in 11 months of 2020 its volume increased to $99 \%$.

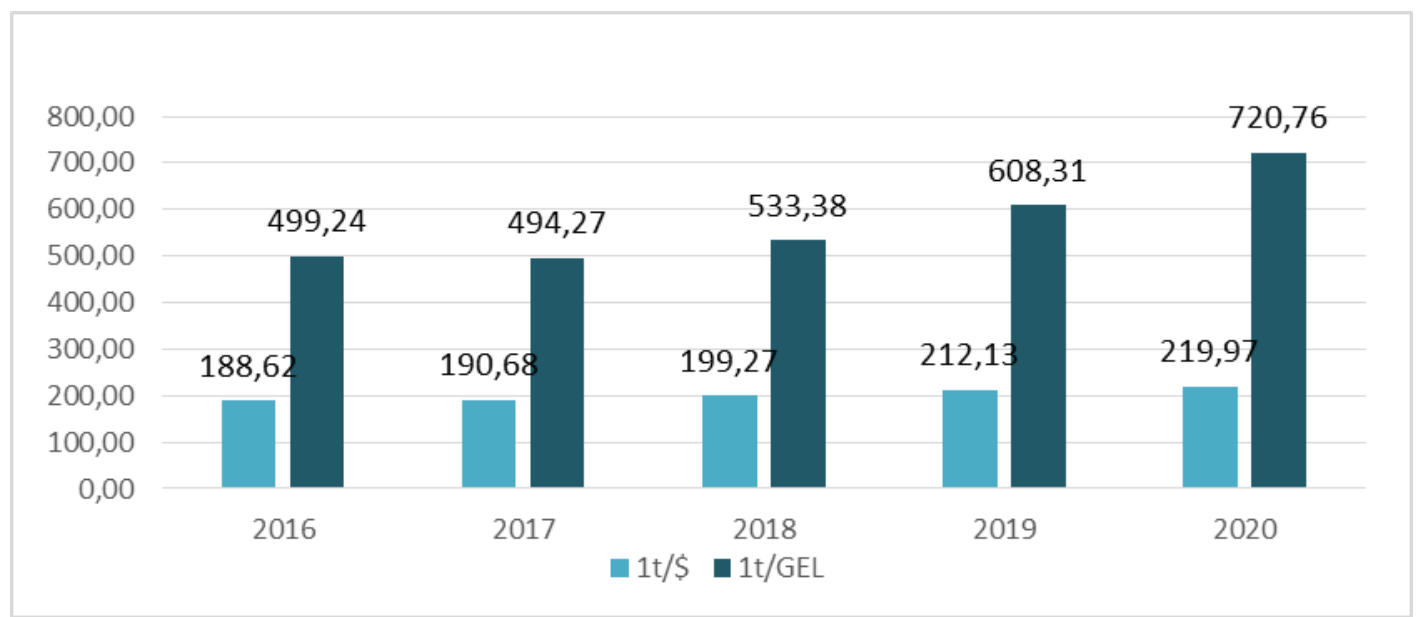

Fig 3. Wheat price dynamics.

Source: Calculated based on statistics by the authors (Georgia, 2021)

Despite the stability of food prices in the world, many countries are experiencing inflation in retail trade, which is caused by COVID-19, currency devaluation and other factors, and leads to a reduction in food supply. Rising food prices has a greater impact on low- and middleincome countries, as the bulk of income in these countries is spent on food, as opposed to highincome countries. Higher retail prices mean more households have to reduce the quantity and quality of food consumed. Subsidizing 9 major food products began in April 2020 to maintain retail prices. These products are: rice, beans, pasta, buckwheat, sugar, wheat, flour, oil and milk powder. The budget of the program was 10 million GEL. In order to provide benefits to the population and bread companies in the conditions of the pandemic, the state program of subsidizing wheat flour was launched on November 30, 2020 by the decision of the Government of Georgia, which will be valid until March 31, 2021. The goal of the program is to maintain the retail selling price of bread. The subsidy will cost 2- 2.5 million GEL per month.
Considering that the economic crisis can not be ended by economic methods, during the crisis the state implements such anti-crisis measures that are aimed at alleviating the social situation of the population and supporting businesses with various tax advantages, budget subsidies, etc. (Papava, Chkuaseli, 2020). In this regard, the anti-crisis economic plan, which had a budget of 3.5 billion GEL, is noteworthy. The following types of anti-crisis plans have been developed: the Ministry of Finance AntiCrisis Plan, the Tourism Activation Anti-Crisis Plan, the Agriculture Anti-Crisis Plan, the Ministry of Economy Anti-Crisis Plan, the Ministry of Health Anti-Crisis Plan, the Education Anti-Crisis Plan, the Development Sector Anti-Crisis Plan. In turn, the agricultural anti-crisis plan "Care for the village" included the following activities: assistance to smallholder farmers, supply of cheap diesel to farmers, reduction of the cost of reclamation services, $50 \%$ grant for agricultural production, $50 \%$ grant for irrigation systems, new banking advantages for agro-production, introduction of international standards to improve the quality of 
agricultural products, agro-insurance of perennial crops, promotion of local milk production, offering grants to cooperatives, direct and sectoral assistance benefited by up to 200,000 farmers. (Anti-Crisis, 2020).

In response to the challenges posed by the pandemic in Georgia and to support farmers, the European Union, in cooperation with FAO and the Ministry of Environment and Agriculture of Georgia, has announced grant co-financing programs. Between March and December 2020, 132 agricultural grants worth more than 8.5 million GEL were awarded to rural farmers, entrepreneurs and small and medium-sized businesses. In 22 municipalities of Georgia, farmers were provided with irrigation systems, agricultural techniques and machinery. Co-financing grants in response to the pandemic are part of a large-scale grant initiative by the European Union and the FAO, which has been implemented in Georgia since 2019 under the European Neighborhood Program for Rural and Agricultural Development (ENPARD).

While working on the article, we communicated with farmers to study the impact caused by the pandemic. The in-depth interview allowed us to do the following analysis: Farmers are mostly satisfied with the measures taken by the state, they have not stopped their activities and continue to work towards expansion, finding new markets, but they still need help in this regard. Most of them benefit from assistance, which is reflected in the purchase of machinery, special equipment, agro-fertilizer, labor tools. Problems were also identified in finding and selling markets, complicating the hiring of seasonal workers due to the pandemic.

As a result of the analysis of these efforts, it can be said that agriculture has not been substantially affected by the coronavirus, as it has been in other sectors - tourism, air transport and others. The reason is that the agricultural sector did not stop production, the Ministry of Agriculture provided support to enterprises and farmers in this sector, as well as regulated food logistics both within the country and abroad. However, the problems associated with the logistics and manufacturing chains still deepened. COVID-19 is likely to be different.
This will probably have a smaller direct impact on agricultural production. This will shock and affect food security mainly in different ways, according to the product and the region. (Laborde, Martin, Swinnen, Vos, 2020).

Changes in the food environment have had a different impact on food supply. In the post-coronavirus period, the category of the self-employed will increase again, as it is expected that the unemployed population in the city and part of the population returning from emigration will move to agriculture. The income received will be small and will be spent only to satisfy family members (Kharaishvili, Natsvlishvili, 2020).

Conclusion. Thus a study of the current state of the agro-food sector shows that the problem of providing the population with food is becoming more acute.

The pace of development of the agro-food sector lags significantly behind the growth rates of other sectors of the economy. The current economic growth has not yet created the conditions for sustainable economic development: The level of supply of essential agro-food products is quite low, the number of jobs has not increased substantially, the level of income is low, poverty rates are still high and the food deficit is filled mainly with imported products.

The issue of food security is still unsolved for Georgia. According to a UN resolution, food security is at risk if the country imports more than $20 \%$ of the products consumed. In Georgia $70 \%$ of food has been imported.

The problems created by the pandemic are many, which have created new challenges and the public and private sectors alike are trying to set foot to these challenges. The state, through subsidies, tax breaks, and financial aid, has helped citizens overcome difficult times and businesses to maintain jobs and production (Kvasha, et al., 2019). During this period, online shopping and delivery services became very popular, which showed the certain activity of citizens.

Despite the support activities, the agrofood sector still needs help. We have developed recommendations, the consideration of which will significantly contribute to the food supply of the markets and the food supply to the population: 
- according to the FAO data, food crisis is expected around the world in the post-pandemic period, and we think that this will be reflected in most of the countries that depend on food imports, including Georgia. We therefore consider it necessary to develop strategic measures that will reduce the country's dependence on food imports;

- in order to ensure food security we consider the regulation of the land fund as the first task. We mean the need to develop a longterm state program to increase soil fertility. Also, to cultivate and use the unexploited and degraded agricultural land. Compared to 1990, when the sown area was 701.9 thousand hectares, in 2019 it has been reduced to 495.2 hectares. Which means that the potential is unused. The state must combat the uncertainty caused by the impact of Covid-19 on demand and supply for food products in order to make appropriate decisions so that the pandemic does not escalate into a food crisis.

In Georgia the priorities for the development of the agricultural food sector should be based primarily on the principles of sustainable food security.
This will solve the problems in the development of the sector by creating systemic approaches and creating a favorable environment for the development of agricultural food markets.

Active communication between entrepreneurs and government officials is necessary due to timely receipt of information on regulations, decisions, grants or government programs.

- Develop special plans and programs for farmers and businesses (especially small farmers) to deal with the pandemic.

- The state must combat the uncertainty caused by the impact of Covid-19 on demand and supply for food products in order to make appropriate decisions so that the pandemic does not escalate into a food crisis.

- The priorities for the development of the agro-food sector in Georgia should be based primarily on the principles of sustainable food security. This will make it possible to solve the problems in the development of the sector by creating systemic approaches and creating a favorable environment for the development of agro-food markets.

\section{REFERENCES}

1. Stopcov (2020). Anti-Crisis Economic Plan, 2020. https://stopcov.ge/ka/gegma

2. Laborde, D., Martin, W., Swinnen, J. \& Vos, R. (2020). COVID-19 Risks To Global Food Security. Science, 369(6503): 500-502. https://science.sciencemag.org/content/369/6503/500

3. Papava, V., \& Chkuaseli, M. (2021). Economic Consequences of the COVID-19 Pandemic and the Economic Ability of a Government as a Factor of Production. International Business \& Economics Studies, 3(2), 67-71.

4. Talikadze, N. (2017). The Impact Of Local Production On Food Independence: Trends And Modern Challenges. Economy - XXI Century. Tbilisi.

5. Kharaishvili E., Natsvlishvili I. (2020). Food Security Challenges In Georgia And Agricultural Development Priorities In The Post-Coronavirus Period. ProEconomy - XXI Century. $\mathrm{Tb}$.

6. Klassen, S. \& Murphy, S. (2020). Equity As Both A Means And An End: Lessons For Resilient Food Systems From COVID-19. World Development, 136, 105104.

7. Laborde, D., Martin, W., Swinnen, J. \& Vos, R. (2020). COVID-19 Risks To Global Food Security. Science, 369(6503), 500-502. https://science.sciencemag.org/content/369/6503/500

8. International Labour Organization 2020). CO COVID-19 And Implications For Agriculture And Food Security. https://www.ilo.org

9. UN (2016). On The Implementation Of The UN 2030 Sustainable Development Goals. Institute For Development Of Freedom Of Information. http://www.parliament.ge/uploads/other/46/46079.pdf 
10. HLPE (2020). Food Security And Nutrition: Building A Global Narrative Towards 2030. A Report By The High Level Panel Of Experts On Food Security And Nutrition Of The Committee On World Food Security, Rome. Http:/Www.Fao.Org/3/Ca9731en/Ca9731en.Pdf).

11. Georgia (2019). Georgia Agriculture And Rural Development Strategy 2021-2027. www.mepa.gov.ge

12. Georgia (2021). Export-Import of Georgian Agri-Food Sector. 2021. https://mepa.gov.ge/ge/reports

13. FAO.(2021). Crop Prospects And Food Situation. Quarterly Global Report. http://www.fao.org/3/cb3672en/cb3672en.pdf

14. Jabnidze, N., Tsetskhladze, L., Meskhidze, I.( 2020). The Role Of State Programs In The Transformation Of The Agrarian Sector In Ajara A.R. Proceedings Of The 2020 International Conference "Economic Science For Rural Development" No 54 Jelgava, LLU ESAF, 12-15 May 2020, 131-139.

15. Kvasha, S., Pankratova, L., Koval, V., \& Tamošiūnienè, R. (2019). Illicit financial flows in export operations with agricultural products. Intelellectual Economics, 13(2), 195-209.

16. Derii, Zh., Koval, V., \& Sedikova I. (2018). The role of the agricultural sphere in the context of food security. Scientific Bulletin of Polissia, 4(16), 21-27. http://dx.doi.org/10.25140/2410-95762018-4(16)-21-27

17. King, T., Cole, M., Farber, J. M., Eisenbrand, G., Zabaras, D., Fox, E. M., \& Hill, J. P. (2017). Food safety for food security: Relationship between global megatrends and developments in food safety. Trends in Food Science \& Technology, 68, 160-175.

18. O'Hara, S., \& Toussaint, E. C. (2021). Food access in crisis: Food security and COVID19. Ecological Economics, 180, 106859. 